REDUCTION OF $\mathrm{NO}_{x}$ AND $\mathrm{SO}_{2}$ EMISSIONS

$\mathrm{DOE} / \mathrm{PC} / 88918--7$

FROM COAL BURNING PULSE COMBUSTORS

DE9 1005535

Quarterly Technical Progress Report

for the Period April 1, 1990 - June 30, 1990

By

E. A. Powell and B. T. Zinn

August 1990

Work Performed Under Contract No. DE-FG22-88PC88918

For

U. S. Department of Energy

Office of Fossil Energy

Pittsburgh Energy Technology Center

Pittsburgh, Pennsylvania 15236

Receved by OSTI

By

DEC 311990

School of Aerospace Engineering

Georgia Tech Research Corporation

Georgia Institute of Technology

Atlanta, GA 30332

TECHNICAL INFORMATION CENTER

OFFICE OF SCIENTIFIC AND TECHINICAL INFORMATION

UNTTED STATES DEFARTMENT OF ENERGY 
$\mathrm{DOE} / \mathrm{PC} / 88918-7$

Distribution Category - UC-90

\title{
COAL PULSE COMBUSTION RESEARCH
}

Quarterly Technical Progress Report for the Period

April 1, 1990 - June 30, 1990

\section{Prepared by}

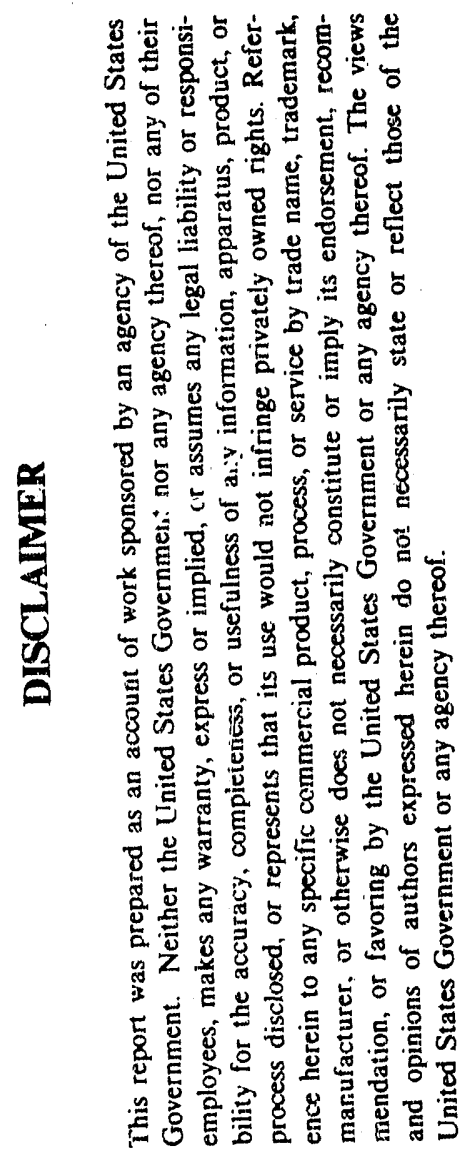

\author{
E. A. Powell and R. T. Zinn \\ School of Aerospace Engineering \\ Georgia Tech Research Corporation \\ Georgia Institute of Technology \\ Atlanta, GA 30332 \\ August 1990 \\ Technical Project Officer - Perry Bergman \\ Prepared for \\ United States Department of Energy \\ Pittsburgh Energy Technology Center \\ Pittsburgh, Pennsylvania
}

Under Contract No. DE-FG22-88FC88918 


\section{ABSTRACT}

Work accomplished during the seventh quarter of Grant No. DE-FG2288PC88918 is presented and discussed. This project is concerned with the reduction of sulfur dioxide and nitrogen oxides emissions from Rijke type coal burning pulse combustors by sorbent addition and combustion staging.

A second series of air staging tests was conducted to determine the effectiveness of substoichiometric primary coal combustion followed by secondary air injection above the bed in reducing the $\mathrm{NO}_{\mathbf{x}}$ emissions. This second group of tests was conducted with total dimensionless air/fuel ratios ranging from 1.1 to 1.4 . For these air staging tests, values of each of the measured quantities were obtained as a function of the total air/fuel ratio, with the primary air/fuel ratio ranging from 0.6 to 0.9 . The secondary air was injected at a height of $52 \mathrm{~cm}$ above the bed. The air staging $\mathrm{NO}_{\mathbf{x}}$ data was compared with the baseline data obtained without air staging. The results indicated that air staging yielded a very significant reduction in $\mathrm{NO}_{\mathrm{x}}$ concentrations when expressed on a zero percent oxygen basis. These reductions in $\mathrm{NO}_{\mathrm{x}}$ emissions, which were small to modest for a primary air/fuel ratio of 0.9 and a total air/fuel ratio of 1.1 , increased significantly as the total air/fuel ratio was increased. Reducing the primary air/fuel ratio from 0.9 to 0.8 resulted in a significant further reduction in $\mathrm{NO}_{\mathrm{x}}$ emissions, but little additional reduction in $\mathrm{NO}_{\mathrm{x}}$ occurred for lower primary air/fuel ratios. For a primary air/fuei ratio of about 0.7 , the reduction in $\mathrm{NO}_{x}$ exhaust concentration due to air staging ranged from about 48 percent at a total air/fue? ratio of 1.1 to about 56 percent for a total air/fuel ratio of 1.4 .

Work began on the investigation of the reduction of sulfur dioxide emissions by the injection of sorbent materials into the Rijke pulse combustor. A pulverized dolomitic limestone material containing 24 percent calcium and 6 percent magnesium was used. The particle size of this material ranged from $0.1 \mathrm{~mm}$ to about $1.0 \mathrm{~mm}$. Initially, difficulties were encountered in feeding and dispersing this material into the combustor. This required extensive modification of the limestone auger feed system and the air entrainment system. The auger was mounted horizontally, and a vibrator was installed on the hopper to ensure a continuous and constant feed rate of sorbent into the air entrainment system. The hopper was pressurized to overcome an air blow-back problem from the air entrainment system. Two series of preliminary tests were conductea with limestone addition. In these tests primary air/fuel ratios ranged from 0.8 to 1.6 , and air staging was not used. For air/fuel ratios of 1.0 and $\mathrm{Ca} / \mathrm{S}$ molar ratios between 2.4 and 4.2 , little or no reduction in $\mathrm{SO}_{2}$ emissions was obtained. Increasing the air/fuel ratio to 1.2 for the same $\mathrm{Ca} / \mathrm{S}$ ratios resulted about a 20 percent reduction in the exhaust $\mathrm{SO}_{2}$ concentration. However in these preliminary tests, the residence time of the sorbent particles, oxygen availability in the reaction zone, and reaction temperature were probably not in the optimum range for sulfur dioxide capture. 


\section{INTRODUCTION}

The following report summarizes work done under DOE Grant No. DE-FG-88PC88918 during the period April 1, 1990 through June 30,1990 . This project is concerned with the reduction of sulfur dioxide and nitrogen oxides emissions from Rijke type coal burning pulse combustors by sorbent addition and combustion staging.

The following work will be described in this report: (1) a second series of air staging tests to determine the effectiveness of substoichiometric primary coal combustion followed by secondary air injection above the bed in reducing the $\mathrm{NO}_{\mathbf{x}}$ emissions, (2) continued development of the sorbent feed system, and (3) preliminary tests with limestone addition for reducing $\mathrm{SO}_{2}$ emissions. The report will conclude with projected work to be accomplished during the remaining two months of the project.

\section{AIR STAGING TESTS}

A second group of air staging tests was conducted during the report period. Unlike the first series of air staging tests, in which the final air/fuel ratio was equal to one, this second group of tests was conducted with total air/fuel ratios greater than one. The secondary air was also injected higher above the bed $(52 \mathrm{~cm})$ than in the previous group of air staging tests. This injection height was chosen based on data from the earlier tests which indicated that $\mathrm{NO}_{\mathrm{x}}$ emissions decreased with increasing injection height (see Ref. 1). In this series, as in the previous one, the coal feed rate was $75 \mathrm{~g} / \mathrm{min}$. A total of 16 tests was conducted in this series, each consisting of four or five segments lasting about five minutes each. In each test the primary air/fuel ratio was fixed, while the amount of secondary air and herice the total air/fuel ratio was varied stepwise from 1.1 to 1.4. Tests were conducted for primary air/fuel ratios of $0.9,0.8,0.7$ and 0.6. As in the previous tests, measurements of sound pressure levels, frequencies, and gas compositions $\left(\mathrm{CO}_{2}, \mathrm{CO}, \mathrm{O}_{2}, \mathrm{NO}_{\mathrm{x}}\right.$ and $\left.\mathrm{SO}_{2}\right)$ and gas temperatures were made. However the $\mathrm{CO}$ and $\mathrm{SO}_{2}$ data are 
not relevant to the issue of $\mathrm{NO}_{\mathrm{x}}$ reduction, and they are not included in the results presented herein.

The results of the air staging tests are summarized in Tables I through III and in Figures 1 through 4 . The individual test data are given in Table I for primary dimensionless air/fuel ratios of 0.9 and 0.8 . Each set of values of sound pressure level (SPL), mole fractions of carbon dioxide $\left(\mathrm{CO}_{2}\right)$, oxygen $\left(\mathrm{O}_{2}\right)$, and nitrogen oxides $\left(\mathrm{NO}_{\mathrm{x}}\right)$, and the combustion efficiencies presented in Table $I$ are the time averages over the appropriate test segment in a single air-staging test. For a given primary air/fuel ratio, $\alpha_{1}$, two to four test segments were conducted for each value of the total air/fuel ratio, $\alpha_{t}$. The corresponding time averages for primary air/fuel ratios of 0.7 and 0.6 are given in Table II. The $\mathrm{NO}_{\mathrm{x}}$ emissions data has been reduced to a $0 \%$ oxygen basis using the formula:

$$
\mathrm{NO}_{\mathrm{x}}\left(0 \% \cdot \mathrm{O}_{2}\right)=\left[\mathrm{NO}_{\mathrm{x}}\right] /\left(1-\left[\mathrm{O}_{2}\right] / 0.21\right)
$$

where

$$
\begin{aligned}
& {\left[\mathrm{NO}_{\mathbf{x}}\right]=\text { measured exhaust } \mathrm{NO}_{\mathbf{x}} \text { concentration in ppm }} \\
& {\left[\mathrm{O}_{2}\right]=\text { measured } \mathrm{O}_{2} \text { mole fraction in exhaust }}
\end{aligned}
$$

The combustion efficiency $\eta_{c}$ was calculated using the formula:

$$
\eta_{c}=0.217+\left(0.173\left[\mathrm{CO}_{2}\right]+0.049[\mathrm{CO}]\right) \mathrm{N}_{\mathrm{td}}
$$

where

$$
\begin{aligned}
& {\left[\mathrm{CO}_{2}\right]=\text { measured exhaust } \mathrm{CO} \text { mole fraction }} \\
& {[\mathrm{CO}]=\text { measured exhaust } \mathrm{CO} \text { mole fraction }} \\
& \mathrm{N}_{\mathrm{td}}=\text { total number of moles in exhaust, dry basis }
\end{aligned}
$$


Table I. Air Staging Data for Primary Air/Fuel Ratios of 0.9 and 0.8.

\begin{tabular}{|c|c|c|c|c|c|c|}
\hline $\begin{array}{c}\text { Primary } \\
\text { Air/Fuel } \\
\text { Ratio } \\
\alpha_{1}\end{array}$ & $\begin{array}{c}\text { Total } \\
\text { Air/Fuel } \\
\text { Ratio } \\
\alpha_{t} \\
\end{array}$ & $\begin{array}{l}\text { SPL } \\
(\mathrm{dB})\end{array}$ & $\begin{array}{c}\mathrm{CO}_{2} \\
(\%)\end{array}$ & $\begin{array}{l}\mathrm{O}_{2} \\
(\%)\end{array}$ & $\begin{array}{c}\mathrm{NO}_{\mathrm{x}} \\
\left(0 \% \mathrm{O}_{2}\right) \\
(\mathrm{ppm})\end{array}$ & $\begin{array}{l}\text { Combustion } \\
\text { Efficiency }\end{array}$ \\
\hline 0.9 & 1.1 & 158.1 & 16.3 & 2.95 & 420 & 0.99 \\
\hline 0.9 & 1.1 & 158.9 & 14.8 & 4.77 & 591 & 0.92 \\
\hline 0.9 & 1.1 & 159.1 & 14.8 & 3.33 & 497 & 0.92 \\
\hline 0.9 & 1.1 & 156.1 & 14.5 & 4.90 & 549 & 0.90 \\
\hline 0.9 & 1.2 & 158.6 & 13.6 & 6.35 & 642 & 0.92 \\
\hline 0.9 & 1.2 & 157.6 & 15.3 & 4.19 & 401 & 1.01 \\
\hline 0.9 & 1.2 & 156.6 & 14.1 & 5.42 & 480 & 0.94 \\
\hline 0.9 & 1.2 & 158.5 & 13.5 & 5.15 & 532 & 0.92 \\
\hline 0.9 & 1.3 & 156.9 & 13.3 & 6.19 & 439 & 0.96 \\
\hline 0.9 & 1.3 & 157.2 & 13.5 & 6.11 & 469 & 0.97 \\
\hline 0.9 & 1.3 & 158.9 & 13.1 & 5.53 & 505 & 0.95 \\
\hline 0.9 & 1.4 & 157.3 & 11.7 & 7.65 & 457 & 0.92 \\
\hline 0.9 & 1.4 & 158.6 & NA & 6.55 & 489 & $\mathrm{NA}$ \\
\hline 0.8 & 1.1 & 155.7 & 15.9 & 2.82 & 341 & 0.97 \\
\hline 0.8 & 1.1 & 159.4 & 14.7 & 3.34 & 318 & 0.92 \\
\hline 0.8 & 1.1 & 157.2 & 14.0 & 4.16 & 316 & 0.88 \\
\hline 0.8 & 1.2 & 158.7 & 15.2 & 3.38 & 331 & 1.00 \\
\hline 0.8 & 1.2 & 155.6 & 13.6 & 4.88 & 350 & 0.92 \\
\hline 0.8 & 1.2 & 156.3 & 12.5 & 6.07 & 372 & 0.86 \\
\hline 0.8 & 1.3 & 158.3 & 14.2 & 4.55 & 348 & 1.01 \\
\hline 0.8 & 1.3 & 156.1 & 11.4 & 6.92 & 369 & 0.86 \\
\hline 0.8 & 1.3 & 156.1 & 11.6 & 7.11 & 377 & 0.87 \\
\hline 0.8 & 1.4 & 158.3 & 12.7 & 6.34 & 363 & 0.98 \\
\hline 0.8 & 1.4 & 155.9 & 9.6 & 8.74 & 389 & 0.81 \\
\hline
\end{tabular}


Table II. Air Staging Data for Primary Air/Fuel Ratios of 0.7 and 0.6.

\begin{tabular}{|c|c|c|c|c|c|c|}
\hline $\begin{array}{c}\text { Primary } \\
\text { Air/Fuel } 1 \\
\text { Ratio } \\
\alpha_{1}\end{array}$ & $\begin{array}{c}\text { Total } \\
\text { Air/Fuel } \\
\text { Ratio } \\
\alpha_{t}\end{array}$ & $\begin{array}{c}\mathrm{SPL} \\
(\mathrm{dB})\end{array}$ & $\begin{array}{c}\mathrm{CO}_{2} \\
(\%)\end{array}$ & $\begin{array}{c}\mathrm{O}_{2} \\
(\%)\end{array}$ & $\begin{array}{c}\mathrm{NO}_{\mathrm{x}} \\
\left(0 \% \mathrm{O}_{2}\right) \\
(\mathrm{ppm})\end{array}$ & $\begin{array}{c}\text { Combustion } \\
\text { Efficiency }\end{array}$ \\
\hline 0.7 & 1.2 & 157.0 & 13.4 & 4.76 & 350 & 0.91 \\
\hline 0.7 & 1.2 & 157.2 & 12.4 & 5.68 & 302 & 0.86 \\
\hline 0.7 & 1.3 & 156.5 & 13.2 & 5.42 & 369 & 0.95 \\
\hline 0.7 & 1.3 & 156.8 & 12.9 & 5.93 & 336 & 0.94 \\
\hline 0.7 & 1.4 & 156.5 & 12.8 & 6.25 & 361 & 0.99 \\
\hline 0.7 & 1.4 & 156.3 & 12.6 & 6.44 & 383 & 0.98 \\
\hline 0.6 & 1.1 & 152.7 & 15.3 & 3.57 & 360 & 0.94 \\
\hline 0.6 & 1.2 & 153.2 & 12.4 & 5.99 & 335 & 0.86 \\
\hline 0.6 & 1.2 & 153.1 & 12.3 & 6.07 & 343 & 0.86 \\
\hline 0.6 & 1.2 & 156.4 & 11.8 & 6.33 & 328 & 0.84 \\
\hline 0.6 & 1.3 & 156.2 & 12.4 & 6.16 & 365 & 0.91 \\
\hline 0.6 & 1.3 & 152.4 & 12.7 & 6.15 & 386 & 0.93 \\
\hline 0.6 & 1.4 & 155.9 & 13.1 & 5.32 & 384 & 1.01 \\
\hline 0.6 & 1.4 & 152.7 & 14.5 & 4.93 & 414 & 1.09 \\
\hline
\end{tabular}

For given air staging parameters (i.e., $\alpha_{1}$ and $\alpha_{t}$ ) there were considerable variations in the efficiency of the overall combustion process as reflected in the variations in the exhaust concentrations of $\mathrm{CO}_{2}$ and $\mathrm{O}_{2}$. There were also significant variations in sound pressure levels and $\mathrm{NO}_{\mathrm{x}}$ concentration for tests conducted with identical air staging parameters. The variations in the measured $\mathrm{NO}_{\mathrm{x}}$ concentrations are best seen in Figure 1 where the individual time averaged test data are shown. The largest data scatter occurred for the nominal primary air/fuel ratio of 0.9 , while the scatter was much smaller for the lower $\alpha_{1}$ values. This graph readily shows that the $\mathrm{NO}_{\mathrm{x}}$ emissions were significantly reduced as the primary air/fuel ratio was decreased from 0.9 to 0.8 , but only slight improvements were obtained by further decreases in the primary air/fuel ratio. 
Mean values of sound pressure levels, combustion efficiencies and exhaust $\mathrm{NO}_{\mathrm{x}}$ concentrations were also computed for each set of air staging parameters $\alpha_{1}$ and $\alpha_{t}$ by taking the arithmetic average of the appropriate values shown in Tables $I$ and II. These mean values are given in Table III.

Table III. Averaged Air Staging Data.

\begin{tabular}{|c|c|c|c|c|}
\hline $\begin{array}{c}\text { Primary } \\
\begin{array}{c}\text { Air/Fuel } \\
\text { Ratio } \\
\alpha_{1}\end{array}\end{array}$ & $\begin{array}{c}\text { Total } \\
\text { Air/Fuel } \\
\text { Ratio } \\
\alpha_{i}\end{array}$ & $\begin{array}{c}\text { Sound } \\
\text { Pressure } \\
\text { Level } \\
(\mathrm{dB})\end{array}$ & $\begin{array}{c}\text { Combustion } \\
\text { Efficiency }\end{array}$ & $\begin{array}{c}\text { NO } \\
\text { (0\% Oxygen) } \\
(\mathrm{ppm})\end{array}$ \\
\hline 0.9 & 1.1 & 158.1 & 0.93 & 514 \\
\hline 0.9 & 1.2 & 157.8 & 0.95 & 514 \\
\hline 0.9 & 1.3 & 157.7 & 0.96 & 471 \\
\hline 0.9 & 1.4 & 158.0 & 0.92 & 473 \\
\hline 0.8 & 1.1 & 157.4 & 0.92 & 325 \\
\hline 0.8 & 1.2 & 156.9 & 0.93 & 351 \\
\hline 0.8 & 1.3 & 156.8 & 0.91 & 365 \\
\hline 0.8 & 1.4 & 157.1 & 0.90 & 376 \\
\hline 0.7 & 1.2 & 157.1 & 0.89 & 326 \\
\hline 0.7 & 1.3 & 156.7 & 0.95 & 353 \\
\hline 0.7 & 1.4 & 156.4 & 0.99 & 372 \\
\hline 0.6 & 1.1 & 152.7 & 0.94 & 360 \\
\hline 0.6 & 1.2 & 154.2 & 0.85 & 335 \\
\hline 0.6 & 1.3 & 154.3 & 0.92 & 376 \\
\hline 0.6 & 1.4 & 154.3 & NA & 399 \\
\hline
\end{tabular}

The mean $\mathrm{NO}_{\mathrm{x}}$ concentrations given in Table III were plotted as a function of the total dimensionless air/fuel ratio, $\alpha_{\mathfrak{t}}$, for each value of the primary dimensionless air/fuel ratio, $\alpha_{1}$. These averaged $\mathrm{NO}_{\mathrm{x}}$ data are shown in Figure 2 along with the baseline $\mathrm{NO}_{\mathrm{x}}$ concentrations obtained without air/staging. For the air staging data, 
a linear regression curve fit is shown for each primary air/fuel ratio, while a quadratic curve fit (nonlinear regression) is shown for the baseline data. Comparison of the air-staging curves with the baseline curve reveals that air staging yielded a very significant reduction in $\mathrm{NO}_{x}$ concentrations when expressed on a $0 \%$ oxygen basis. These reductions in $\mathrm{NO}_{\mathbf{x}}$ emissions, which were small to modest for the lowest total air/fuel ratio (1.1), increased significantly as the total air/fuel ratio was increased. Extrapolation of the linear regression lines to $\alpha_{t}=1.0$ shows that only small reductions or even increases $\left(\alpha_{1}=0.9\right)$ in $\mathrm{NO}_{\mathbf{x}}$ emissions occur with air staging to final stoichiometric conditions, a result in agreement with the results presented in the previous report (Ref. 1). The largest reductions in $\mathrm{NO}_{\mathrm{x}}$ occurred when going from no air staging (baseline) to air staging with a primary air/fuel ratio of 0.9. Significant further reductions in $\mathrm{NO}_{x}$ occurred with further reduction in the primary air/fuel ratio to 0.8 , but little additional reduction in $\mathrm{NO}_{\mathrm{x}}$ emissions was obtained with lower primary air/fuel ratios. Close examination of Figure 2 shows that the optimum primary air/fuel ratio for $\mathrm{NO}_{\mathrm{x}}$ reduction is about 0.7. For this case the reduction in $\mathrm{NO}_{x}$ exhaust concentration due to air staging ranged from about 48 percent at $\alpha_{t}=1.1$ to about 56 percent at $\alpha_{\mathrm{t}}=1.4$.

The averaged sound pressure levels from Table III are plotted in Figure 3. For the air staging tests with primary air/fuel ratios of 0.7 to 0.9 , sound pressure levels wers generally about 2 to 4 decibels lower than those obtained without air staging (about $160 \mathrm{~dB}$ ). This reduction in pulsation amplitude was expected since the combustion process no longer is completed at the optimum location in the Rijke tube (i. e., the point one fourth of the distance from the upstream end to the downstream end). With air staging, a significant fraction of the heat addition occurs in the region where the secondary air is injected, which is nearer to the midpoint of the tube. Even lower pulsation amplitudes, from 6 to 7 decibels lower than $t$ iseline levels, were obtained when the primary air/fuel ratio was 0.6 . 
The averaged combustion efficiencies from Table III are plotted in Figure 4. These efficiencies ranged from about 85 percent to 99 percent. Only for primary air/fuel ratios of 0.9 and 0.8 is the combustion efficiency lower for the lower primary air/fuel ratio for all total air/fuel ratios tested. Thus the combustion efficiency is significantly influenced by factors other than the pulsation amplitude, since sound pressure levels generally decrease with decreasing primary air/fuel ratio. One factor of considerable variability which influenced the combustion efficiency was the amount of unburned carbon in the refuse which fell through the rotating bed grid.

\section{SORBENT FEED SYSTEM}

Two dolomitic limestone materials were obtained for use as sulfur capturing agents. Both are commercially available agricultural liming products used for reducing the acidity of soils. One of the materials is in a pelletized form with particle sizes between about 0.5 and $2 \mathrm{~mm}$, while the other material is in finely pulverized form with most of the particle sizes between $0.1 \mathrm{~mm}$ and $1.0 \mathrm{~mm}$. The mass median diameter of the pulverized limestone is $0.4 \mathrm{~mm}$. The pelletized dolomitic limestone contains about $2.4 \%$ calcium and $8 \%$ magnesium, while the pulverized material consists of $24 \%$ calcium and $6 \%$ magnesium.

The pelletized material was found to be too coarse to pass through the auger feed and air entrainment system. This material is more suitable for mixing with the coal and introducing it into the combustor along with the coal using the coal feed system. On the other hand the pulverized limestone was found to unsuitable for directly mixing with the coal. Because the limestone particles are much smaller than the coal particles, they tend to settle to the bottom of the hopper by falling through the spaces between the coal particles. Thus uniform delivery of the limestone at a fixed $\mathrm{Ca} / \mathrm{S}$ ratio is impossible by this method. 
Attempts were made to feed the pulverized dolomitic limestone into the air entrainment system. Two difficulties were encountered. First, after filling the hopper with limestone, the auger would feed for only about a minute before a cavity formed in the limestone around the entrance to the auger. This phenomenon, referred to as "bridging" or "rat-holing", is commonly encountered when attempting to transport finely pulverized materials. The second problem was that at the required air flow rates the pressure at the venturi throat was greater than atmospheric pressure, resulting in air "blowback" through the auger and out through the hopper. Of course during blowback conditions, it was impossible to feed limestone into the venturi. Because of design modifications needed to correct these two problems, the series of sorbent addition tests was delayed. However a few preliminary tests were conducted near the end of the quarter which will be described in the next section of this report.

In order to correct the "bridging" problem the limestone feed system was modified. The vertical auger configuration shown in Reference 1 was abandoned in favor of a horizontal auger configuration as shown in Figure 5. This replaced the originally vertical auger entrance aperture with one horizontally oriented. In the horizontal configuration gravity should be more effective in maintaining flow to the auger and preventing bridging. However, tests with the horizontal auger revealed that bridging was still a serious problem. These tests also showed that cavity formation could be prevented by manually stirring the limestone at the bottom of the hopper with a steel rod. This suggested that mechanical vibration of the entire limestone feed system could alleviate the bridging problem. A motor driven vibrator was obtained and mounted on one side of the limestone hopper as shown in Figure 5. The feed system was itself mounted on a separate stand so that it is free to vibrate and to eliminate transmission of vibrations to the combustor and other components. 
In order to eliminate the "blowback" problem, the limestone entrainment venturi was modified to have an adjustable throat area. This "venturi" serves as a transition from circular cross-section tubing to a rectangular cross-section entrainment section and back to circular tubing again. The rectangular cross-section is needed in order to give a flush fit with the exit end of the auger. To prevent the possibility of clogging, the minimum allowable throat area was about $0.8 \mathrm{~mm}$. Tests indicated that reducing the throat area reduced the throat pressure to below atmospheric pressure in the absence of limestone, but the throat pressure became greater than atmospheric pressure when limestone was introduced into the venturi. This increased pressure, which again resulted in blowback through the auger and hopper, was due to the increased downstream resistance caused by the presence of the limestone particles. To prevent blowback the hopper was modified so that it could be pressurized. A steel cover plate was welded to the top of the hopper. A threaded pipe connection allowed filling of the hopper with limestone, after which an air supply line was connected. The dust seal bearing at the base of the auger shaft was also modified to allow pressurization to prevent dust blowback into the laboratory. Subsequent tests revealed that these modifications, which are also shown in Figure 5, successfully eliminated the blowback problem.

\section{PRELIMINARY TESTS WITH LIMESTONE ADDITION}

Two series of preliminary tests with sorbent addition were conducted during the report period. The first series of tests was conducted before the modifications of the limestone feed system were completed, and the air entrainment system could not be used. Instead the limestone auger was temporarily arranged to feed the limestone directly into the coal delivery tube. Thus the limestone and coal were fed together directly onto the coal bed grid during this series of tests. The second series of tests was conducted after the modifications of the sorbent addition system were completed. The air entrainment system was utilized, and the limestone was injected into 
the combustor just above the exit of the coal feed tube. In both series of tests the pulverized dolomitic limestone was used.

Each test in the first series was divided into two to five test segments. In the first test segment the combuior was operated in the pulsating mode for several minutes without sorbent addition. In subsequent test segments dolomitic limestone was added at rates corresponding to $\mathrm{Ca}^{\mathrm{S}} \mathrm{S}$ mole ratios ranging from 2.4 to 4.2 . The coal feed rate was $75 \mathrm{~g} / \mathrm{min}$ for all of the tests. In most of the test segments the dimensionless primary air/fuel ratio was 1.0 with no secondary air injection (air staging). In the remain:ng test segments the primary air/fuel ratio ranged from 1.1 to 1.6, again without air staging. The gas sampling and analysis system was used to determine sulfur dioxide concentrations in tle exhaust gases for all of the test segments. The results were reduced to a $0 \%$ oxygen basis in all cases.

The results of the first series of limestone addition tests are shown in Figures 6 and 7. In Figure ", sulfur dioxide concentrations aie shown for all test segments with dimensionless air/fuel ratios of 1.0 and 1.2. The $\mathrm{SO}_{2}$ concentrations obtained with limestone addition can be compared with those obtained without limestone addition $(\mathrm{Ca} / \mathrm{S}=0)$. For the cases with $\alpha=1.0$, there is no evidence in the data for $\mathrm{SO}_{2}$ reduction when the limestone was added. For the cases with $\alpha=1.2$, there appears to be a reduction of about $20 \%$ in $\mathrm{SO}_{2}$ emissions when compared with the $\alpha=1.0$ case. In Figure 7, the effect of primary air/fuel ratio upon $\mathrm{SO}_{2}$ concentrations are shown for a $\mathrm{Ca} / \mathrm{S}$ mole ratio of 4.2 . Here the individual data are plotted for all of these test segments along with a linear regression curve fit. This shows a definite trend of decreasing $\mathrm{SO}_{2}$ emissions when the dimensionless air/fuel ratio is increased. This result can be explained by the fact that some residual oxygen is needed in order to complete the sulfur capture process; that is, to convert the $\mathrm{SO}_{2}$ into $\mathrm{CaSO}_{4}$.

Three tests were conducted in the second series, where the limestone was injected into the combustor using the air entrainment system. Each test was divided into three test segments, with the first 
test segment being conducted without limesione addition. In the other test segments, limestone was added with $\mathrm{Ca} / \mathrm{S}$ ratios ranging from 3.6 to 8.0. In the first two tests the primary air/fuel ratio was 1.0 , while a small amount of secondary air was needed for injection of the limestone. In the third test, the primary air/fuel ratio was 0.8 . The coal feed rate was $75 \mathrm{~g} / \mathrm{min}$ for all of the test segments. Measured $\mathrm{SO}_{2}$ concentrations indicated that little or no reduction in $\mathrm{SO}_{2}$ occurred as a result of the limestone injection even at the highest $\mathrm{Ca} / \mathrm{S}$ ratio used.

There are three factors that are probably involved in the failure of the limestone addition to result in significant reduction in sulfur dioxide in these preliminary tests: residence time, oxygen availablity, and reaction temperature. When the limestone was introduced through the coal delivery tube or through the air entrainment system, the larger limestone particles fell to the coal bed where the temperature was ton high for effective sultur dioxide capture, while the smallest particles were rapidly carried out with the flow of the exhaust gases. For adequate residence time for sulfur dioxide removal, the limestone particles should be of an intermediate size so that they neither fall to the bed nor are rapidly elutriated. Also the primary combustion zone should be provided with excess air to provide adequate residual oxygen needed for sulfur dioxide removal. Finally a means of temperature control in the region immediately above the bed is needed in order to maintain the gas temperature in the optimum range for sulfur dioxide capture.

\section{FUTURE WORK}

The experimental work on the reduction of nitrogen oxides emissions by means of air staging has been completed. After additional analysis of the data, the final results will be presented in the Final Technical Report on this project. Also a paper describing these results will be prepared and submitted to a journal in the combustion field. 
During the final two months of this project, additional tests will be conducted with modifications in the limestone addition procedure and operating parameters to determine if significant reductic ns in sulfur dioxide emissions can be "btained in the Rijke combustor. One of the modifications will be the insta!ls ion of a water cooled ccil extending from about $5 \mathrm{~cm}$ below the linnestone injector to about 15 $\mathrm{cm}$ above the injectr:-. These tests will all be conducted with excess air in the primary combustion zone in order to provide adequate oxygen for sulfur dioxide removal. Finally the limestone will be further pulverized to reduce the size of the larger particles and sieved to remove the smaller particles in order to obtain particles of about $0.5 \mathrm{~m} \mathrm{~m}$ in diameter.

\section{REFERENCFS}

1. Powell, E. A. and Zinn, B. T., "Reduction of $\mathrm{NO}_{\mathrm{x}}$ and $\mathrm{SO}_{2}$ Emissions from Coal Buraing Pulse Combustors," Quarterly Technical Progress Report for the Period January 1, 1990 March 31, 1990. Work performed under U.S. Dept. of Energy Contract No. DE-FG22-88PC88918, May 1990. 


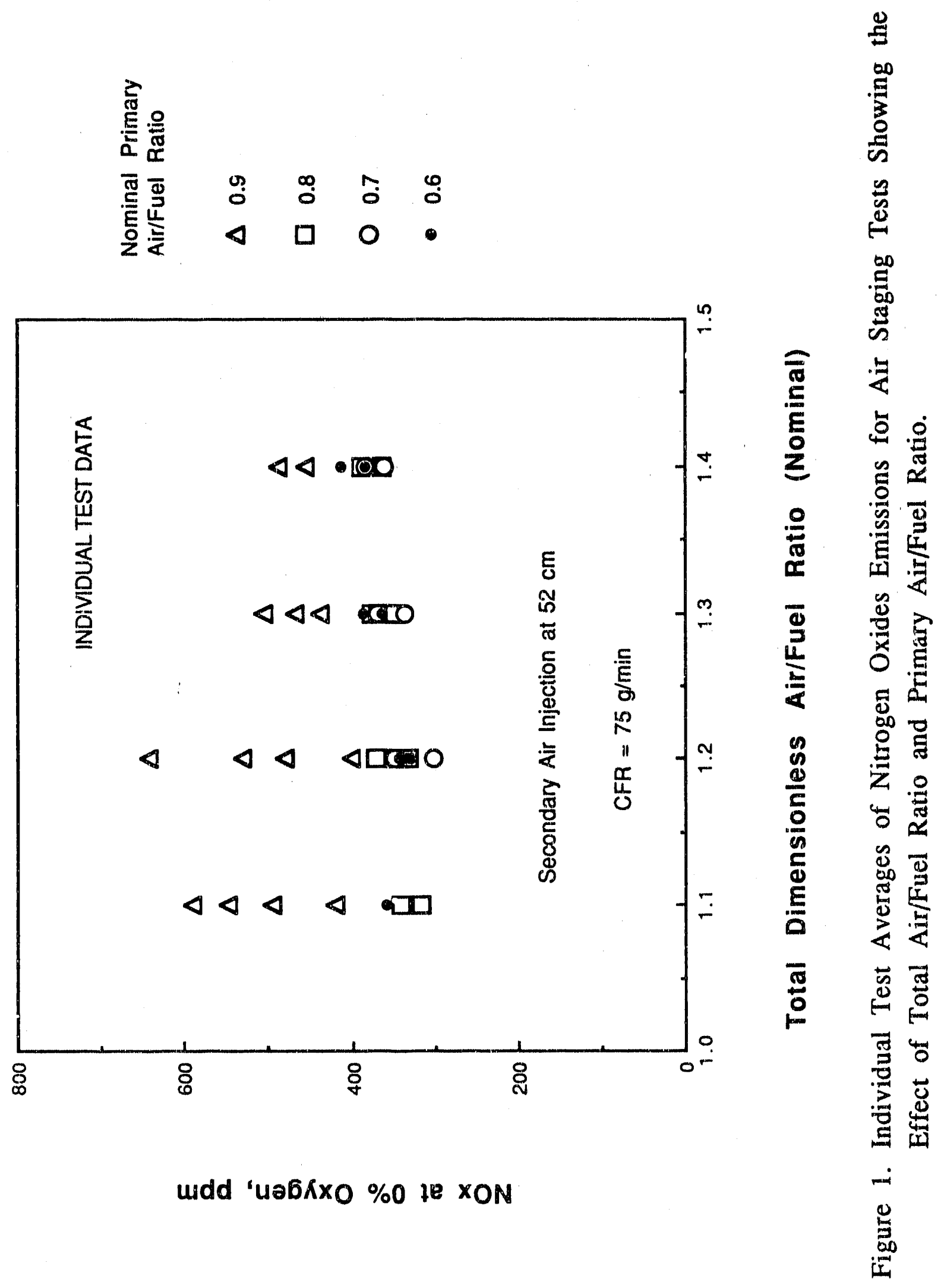




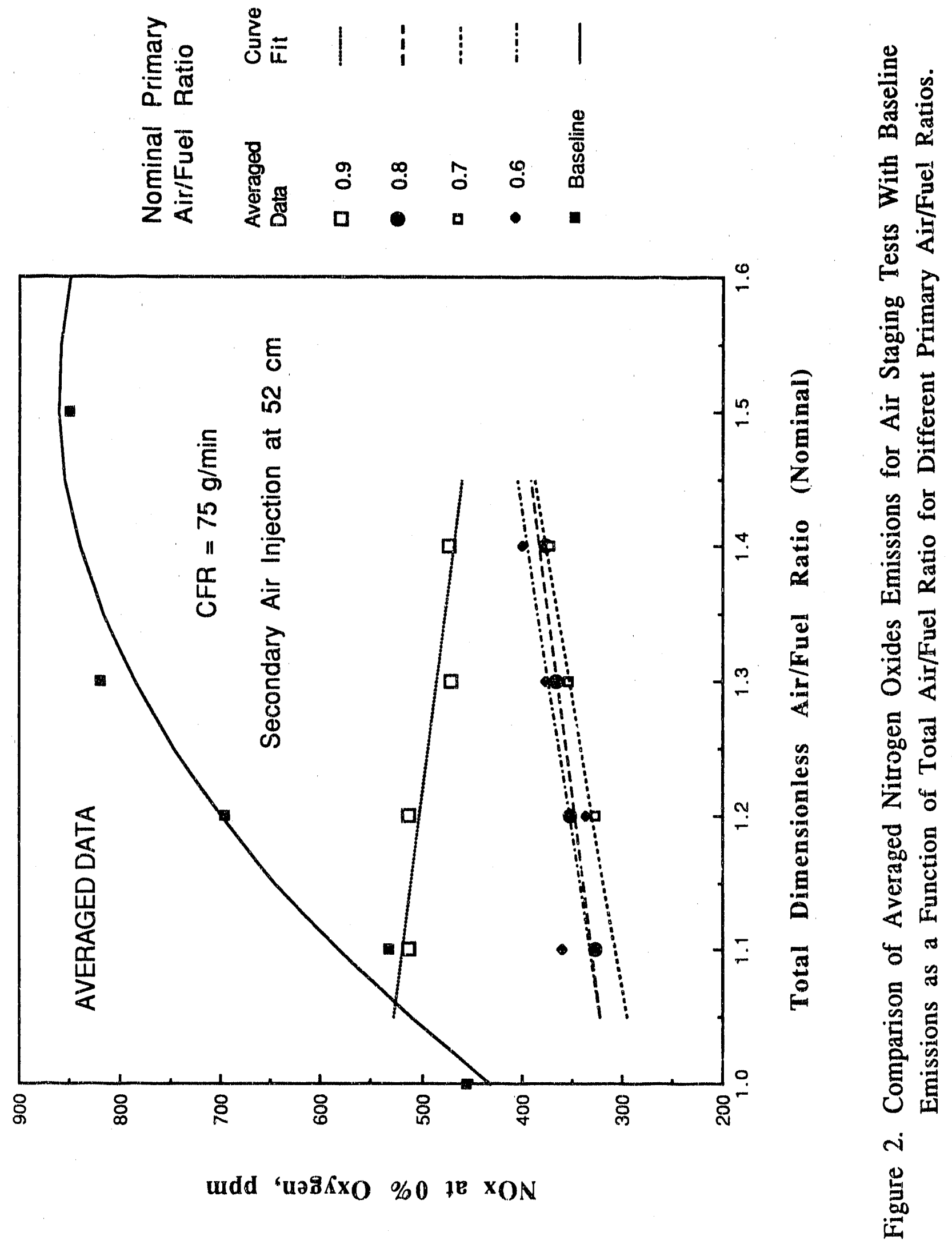




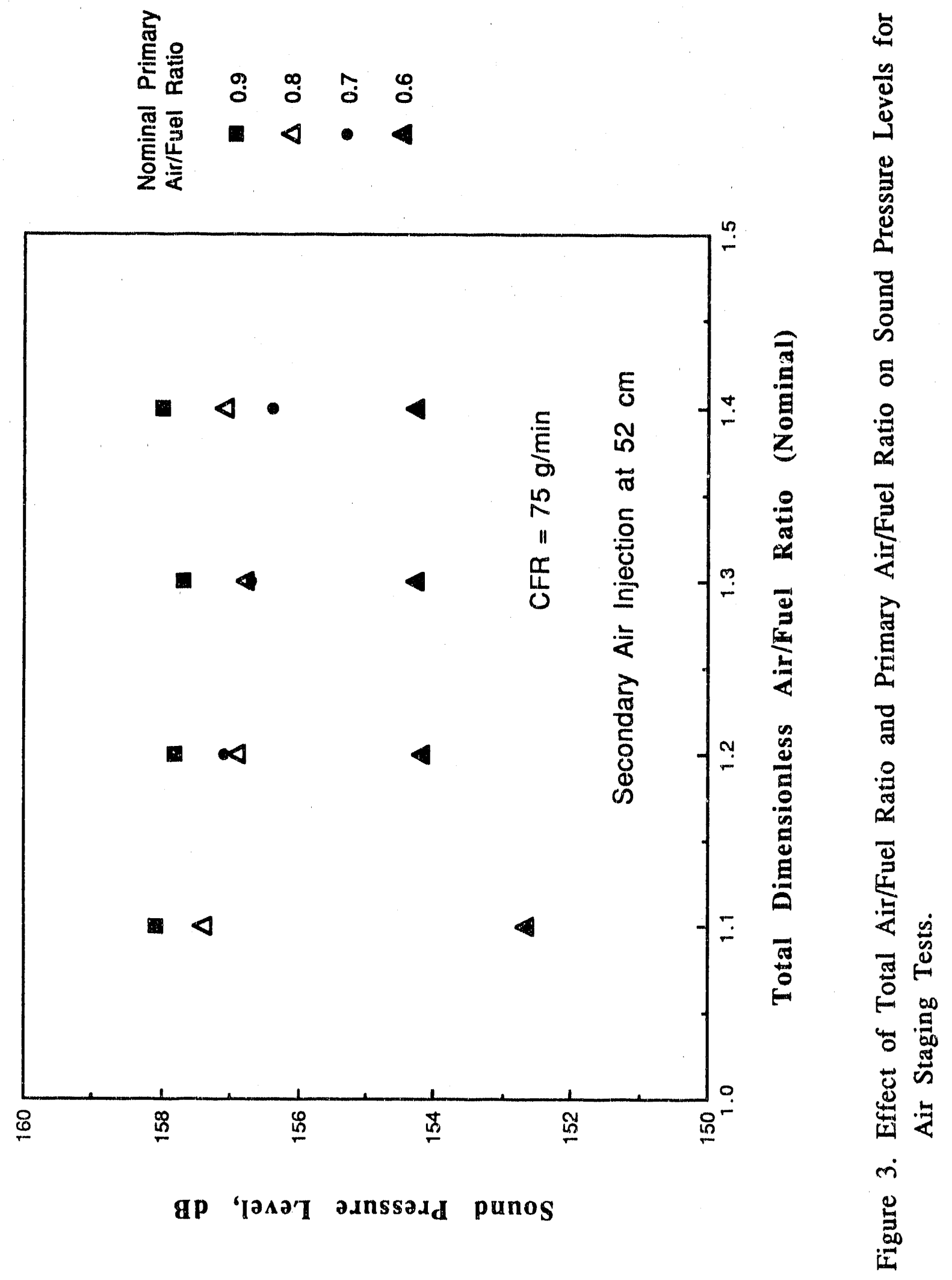



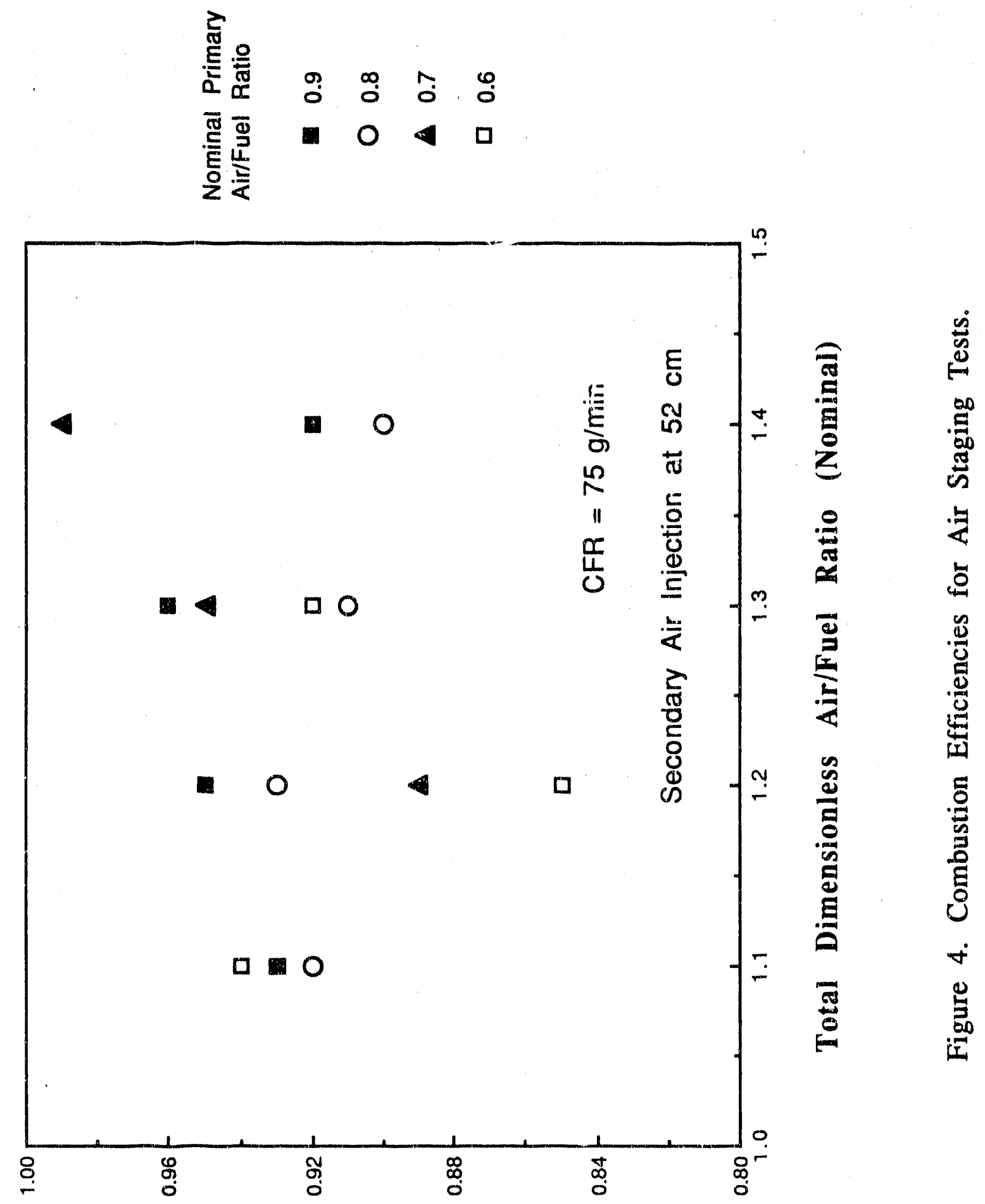

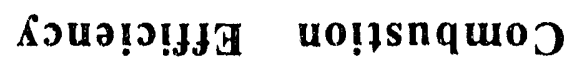




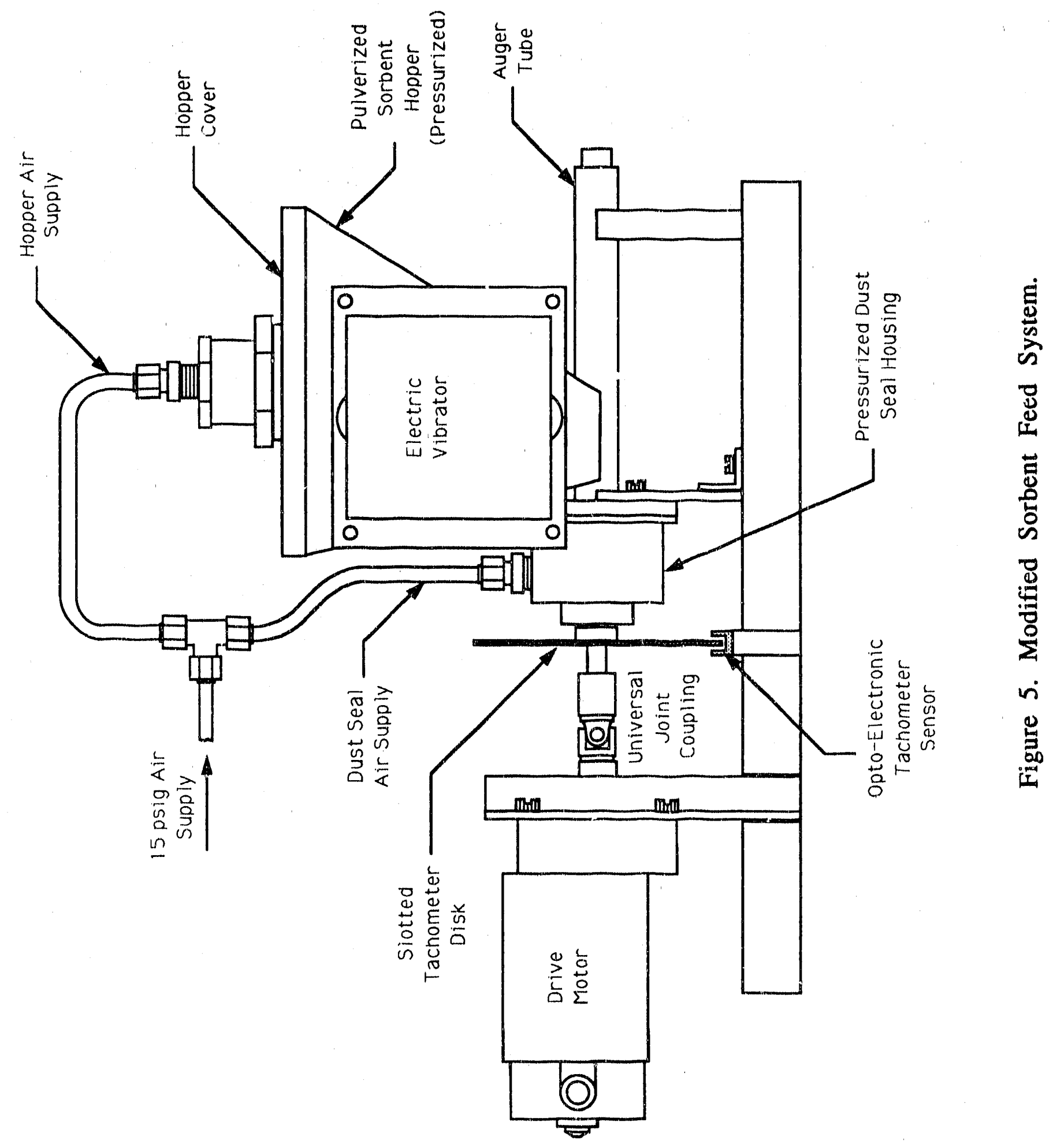




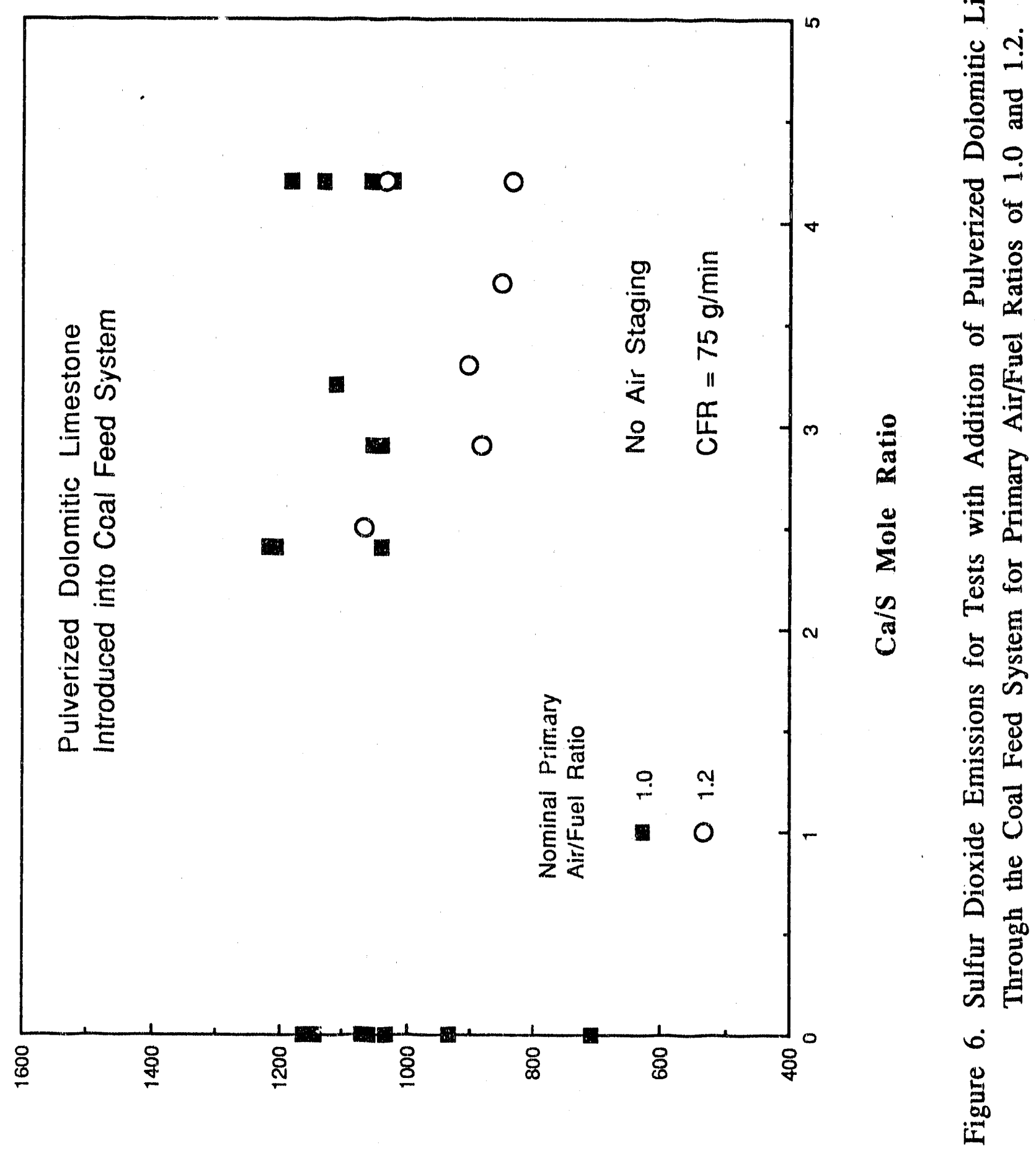

undd 'นวริโxO \%0 ๆอ ZOS 


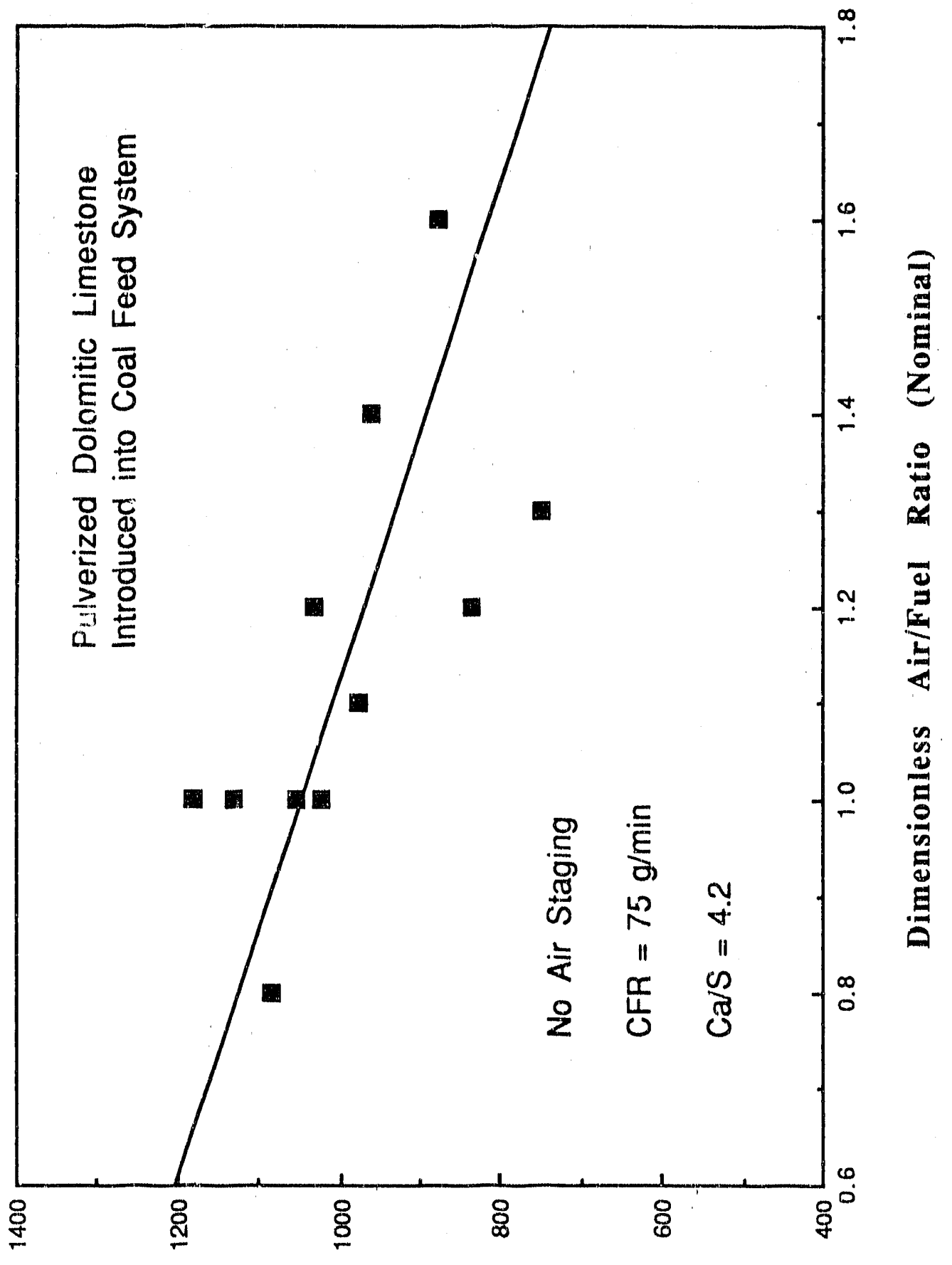

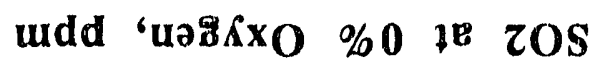



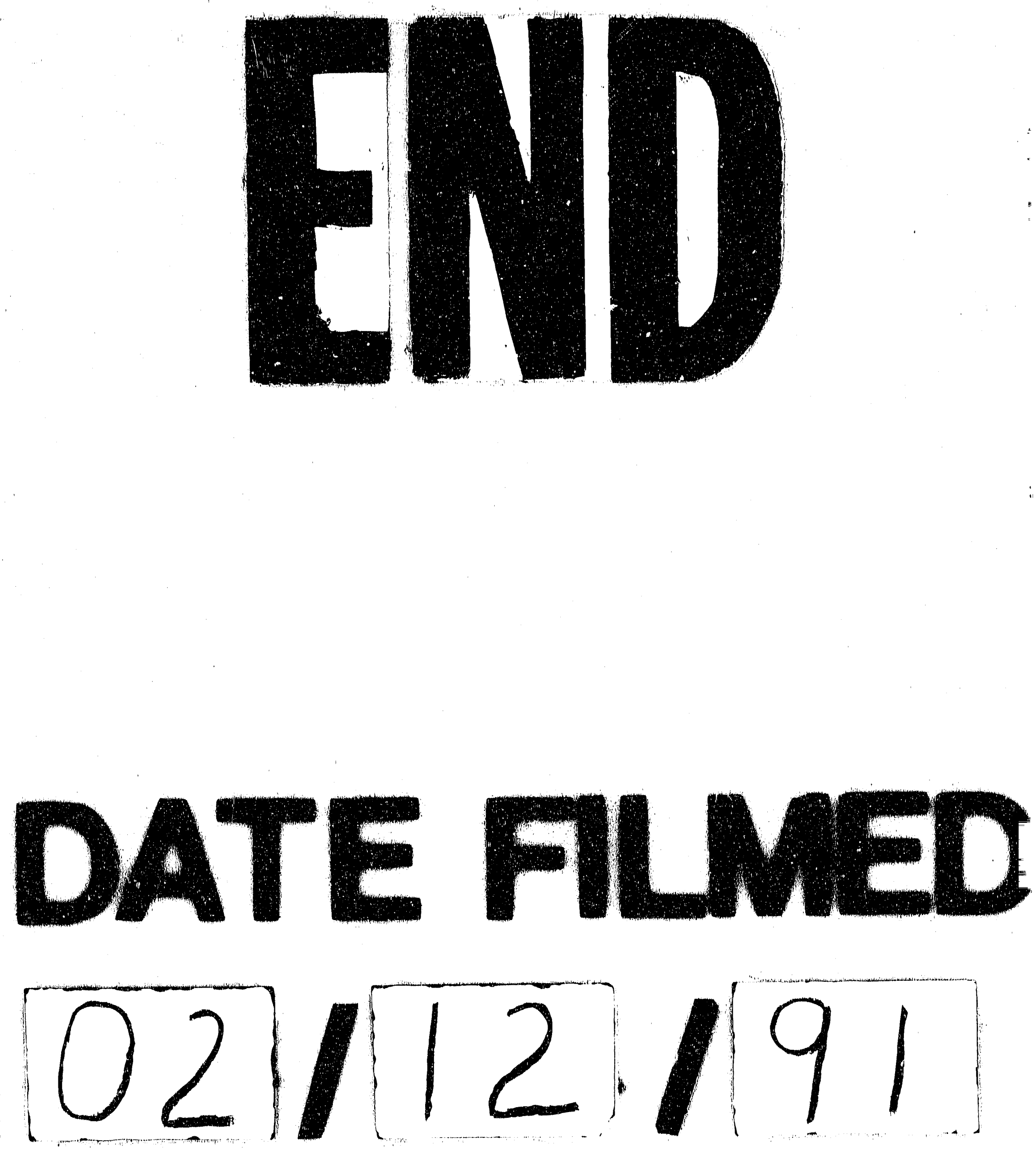
